University of Nebraska - Lincoln

DigitalCommons@University of Nebraska - Lincoln

Agronomy \& Horticulture -- Faculty Publications

Agronomy and Horticulture Department

$11-1984$

\title{
Effect of Freezing on the Hydrocyanic Acid Potential of Field- Grown Sorghum Tillers
}

\author{
Francis A. Haskins \\ University of Nebraska-Lincoln, fhaskins@neb.rr.com \\ Herman J. Gorz \\ United States Department of Agriculture \\ R. M. Hill \\ University of Nebraska-Lincoln \\ J. Brakke Youngquist \\ University of Nebraska-Lincoln
}

Follow this and additional works at: https://digitalcommons.unl.edu/agronomyfacpub

Part of the Plant Sciences Commons

Haskins, Francis A.; Gorz, Herman J.; Hill, R. M.; and Youngquist, J. Brakke, "Effect of Freezing on the Hydrocyanic Acid Potential of Field-Grown Sorghum Tillers" (1984). Agronomy \& Horticulture -- Faculty Publications. 269.

https://digitalcommons.unl.edu/agronomyfacpub/269

This Article is brought to you for free and open access by the Agronomy and Horticulture Department at DigitalCommons@University of Nebraska - Lincoln. It has been accepted for inclusion in Agronomy \& Horticulture -Faculty Publications by an authorized administrator of DigitalCommons@University of Nebraska - Lincoln. 


\title{
Effect of Freezing on the Hydrocyanic Acid Potential of Field-Grown Sorghum Tillers ${ }^{1}$
}

\author{
F. A. Haskins, H. J. Gorz, R. M. Hill, and J. Brakke Youngquist ${ }^{2}$
}

\begin{abstract}
Tissue disruption caused by freezing and thawing may contribute to rapid enzymatic breakdown of dhurrin [ $p$-hydroxy-(S)mandelonitrile- $\beta$-D-glucoside], the cyanogenic glucoside of sorghum [Sorghum bicolor (L.) Moench], but published reports are not in agreement as to the effects of freezing on the hydrocyanic acid potential (HCN-p) of field-grown sorghum leaves. These effects were investigated in a series of experiments in the fall of 1983, a period during which weather conditions at Lincoln, NE permitted repeated sampling of frozen and nonfrozen leaves of field-grown sorghum tillers. Assays of these samples, both spectrophotometrically and with the cyanide electrode, indicated that the HCN-p of KS8 and N32 tiller leaves decreased after the tissue was frozen, but potentially dangerous levels remained in N32 tillers for at least 6 or 7 days after the leaves were frozen. Levels of HCN-p in KS8 tiller leaves were much lower than those in N32 leaves. $p$-Hydroxybenzoic acid, identified by its ultraviolet absorbance spectrum and chromatographic behavior, was found in extracts of frozen N32 tillers. Freezing and thawing of the tillers evidently led to partial breakdown of dhurrin to $p$-hydroxybenzaldehyde and subsequent oxidation of this aldehyde to $p$-hydroxybenzoic acid.
\end{abstract}

Additional index words: Cyanogenesis, Dhurrin, $p$-Hydroxybenzaldehyde, $p$-Hydroxybenzoic acid, Sorghum bicolor (L.) Moench.

$\mathrm{K}$ OJima et al. (6) have shown that in leaves of sorghum [Sorghum bicolor (L.) Moench] seedlings the cyanogenic glucoside, dhurrin [ $p$-hydroxy(S)-mandelonitrile- $\beta$-D-glucoside], is confined to epidermal tissue, but the enzymes responsible for dhurrin degradation, dhurrin $\beta$-glucosidase and hydroxynitrile lyase, are localized in mesophyll tissue. They concluded that physical separation of dhurrin from catabolic enzymes prevents degradation of dhurrin in intact leaves. However, mechanical disruption of the leaf tissue leads to mixing of the enzymes with dhurrin, with the result that the glucoside is broken down to glucose, $p$-hydroxybenzaldehyde $(p-\mathrm{HB})$, and HCN.

Tissue disruption can occur naturally in field-grown plants through freezing and thawing. Freezing and thawing of field-grown sorghum plants may result in dhurrin degradation if the enzymes of dhurrin catabolism are present in the plants and if the enzymes remain active following freezing and thawing. The need to allow time for dhurrin breakdown and $\mathrm{HCN}$ dissipation before previously frozen sorghum forage is fed to livestock has been recognized for some time. Harrington (4) recommended that at least 3 days should elapse between the time sorghum forage is exposed to a killing frost and the time the forage is fed to livestock. Harrington also reported that frost

\footnotetext{
${ }^{1}$ Contribution from USDA-ARS and the Nebraska Agric. Exp. Stn., Lincoln 68583. Published as Paper no. 7425, Journal Series, Nebraska Agric. Exp. Stn. Received 19 Mar. 1984. The work reported was done under Nebraska Agric. Exp. Stn. Project 12-114.

${ }^{2}$ George Holmes professor of agronomy; supervisory research geneticist, USDA-ARS, and professor of agronomy; associate professor of agricultural biochemistry; and research technologist in agronomy, respectively.
}

(nonkilling, presumably) increased the hydrocyanic acid potential (HCN-p) of sorghum forage. Wattenbarger et al. (9) concluded that differing observations on the effects of frost and freezing on HCN-p in sorghum could perhaps be attributed to failure to distinguish between nonkilling frost and freezing. Like Harrington, they found that nonkilling frost usually increased HCN-p. Freezing, however, resulted in death of the plants and rapid loss in $\mathrm{HCN}$ p.

At Lincoln, NE, weather conditions in the fall of 1983 allowed repeated sampling of frozen and nonfrozen leaf tissue from sorghum tillers. These samples were used in a series of experiments the objectives of which were a) to determine the effects of tissue freezing on HCN-p, and b) to identify a 280 $\mathrm{nm}$ absorbing compound that was detected in extracts of some of the frozen leaves.

\section{MATERIALS AND METHODS}

Tillers from field-grown plants of the A-lines of KS8 (7) and N32 (8) sorghum were used in these experiments. As previously reported (5), whole shoots of week-old chambergrown seedlings of both lines had HCN-p values of about $2200 \mathrm{mg} \mathrm{kg}^{-1}$ dry wt., but leaves of field-grown N32 plants approaching maturity were several fold higher in HCN-p than those of KS8.

On 23 Sept. 1983 a freeze killed the upper leaves of the main stems and taller tillers of both KS8 and N32. The dead upper leaves formed a canopy that appeared to protect the younger tillers from freezing until 13 October when tips of many of the tiller leaves were frozen. A freeze that killed all tillers occurred on 11 November. Samples used in these experiments were harvested between 10 Oct. and 22 Nov. 1983.

Tillers 30 to $50 \mathrm{~cm}$ tall were harvested and immediately carried to the laboratory where all leaf tissue distal to the collar of the youngest leaf with a readily visible collar was excised. The leaves were wiped free of dust and debris and were cut into $1-\mathrm{cm}^{2}$ pieces. Random samples of the tissue were then weighed for treatment and assay.

Procedures for sample treatment and for the spectrophotometric assay of HCN-p have been described $(3,5)$. Briefly, samples were either autoclaved fresh (Treatment 1) or were dried $2 \mathrm{~h}$ at $75^{\circ} \mathrm{C}$, ground, and incubated in water for $2 \mathrm{~h}$ at room temperature to provide extracts which were then autoclaved (Treatment 2) or hydrolyzed in base (Treatment 3). For Treatments 1 and 2, $p$-HB released from dhurrin by autoclaving was extracted with ether, the ether was evaporated, and the absorbance at $330 \mathrm{~nm}$ (the $\lambda_{\max }$ of $p$-HB) of the reconstituted ether phase served as the basis for calculation of HCN-p (5). For Treatment 3, the gain in $\mathrm{A}_{\mathbf{3 9 0}}$ between a spectral scan made immediately after the tissue extract was diluted in $0.1 \mathrm{M} \mathrm{NaOH}$ and a scan of the basic solution made about $3 \mathrm{~h}$ later, following dhurrin hydrolysis, provided values needed for calculation of HCN-p (5).

For comparison with the spectrophotometric assays, $\mathrm{HCN}$ from 20 samples representing both KS8 and N32 was distilled into base as in the AOAC procedure for cyanide (1). 
The cyanide contents of the distillates were determined with an ion-selective electrode.

Identification of $p$-hydroxybenzoic acid ( $p$-HBA) in some of the extracts involved partitioning into ether at $\mathrm{pH} 3.1$, ascending paper chromatography with Whatman no. $1^{3}$ filter paper, and spectral scanning as described in Results and Discussion.

\section{RESULTS AND DISCUSSION}

The tillers sampled on 10 October had no apparent frost damage. However, plants were heavily frosted on the mornings of 13 and 14 October, and leaf blades sampled on 14 October had extensive areas that ap- peared water-soaked, indicating that they had been frozen, especially near their tips. For treatment and assay of samples taken on 14, 17, 20, and 24 October, the previously frozen leaf tissue was separated from tissue that did not appear water-soaked. Frozen N32 tissue harvested on 14 October was slightly lower in HCN-p than nonfrozen tissue (Fig. 1), but differences between frozen and nonfrozen samples were much more pronounced in the N32 samples taken on 17 ,

\footnotetext{
${ }^{3}$ Mention of a trademark or proprietary product does not constitute a guarantee or warranty of the product by the USDA or the Univ. of Nebraska and does not imply its approval to the exclusion of other products that may also be suitable.
}

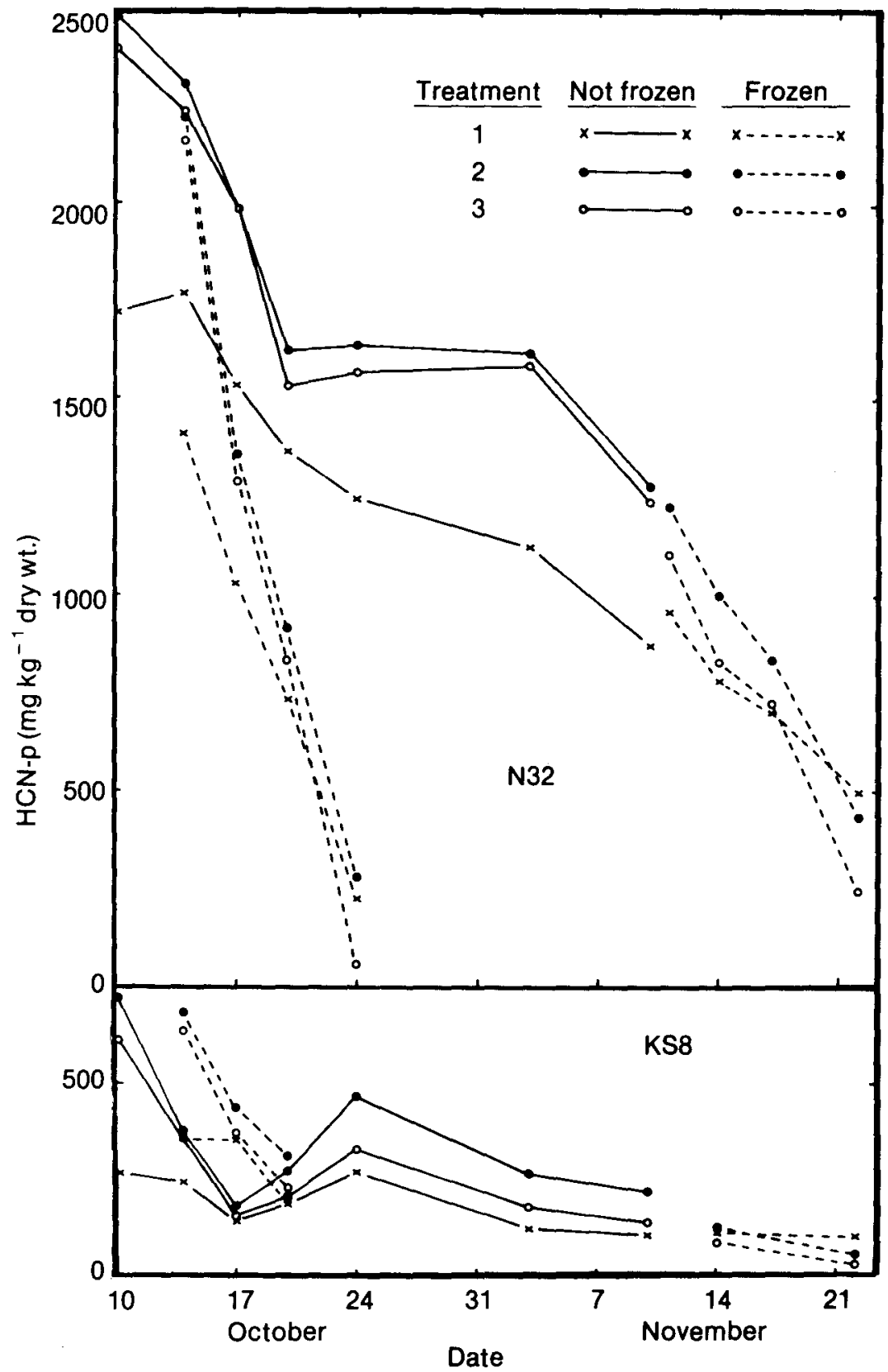

Fig. 1. Hydrocyanic acid potential (HCN-p) of nonfrozen and frozen leaf tissue harvested from tillers of KS8 and N32 sorghum during the fall of 1983 . Treatments: $1-2.00 \mathrm{~g}$ fresh tissue was autoclaved $30 \mathrm{~min}$ in $100 \mathrm{~mL}$ water; 2 and 3-tissue was dried at $75^{\circ} \mathrm{C}$ for $2 \mathrm{~h}$ and ground through 1-mm screen, and the equivalent of $2.00 \mathrm{~g}$ of fresh tissue was extracted with $100 \mathrm{~mL}$ of water at room temperature after which dhurrin in the resulting extract was hydrolyzed by autoclaving 30 min (Treatment 2) or by standing $3 \mathrm{~h}$ in $0.1 \mathrm{M} \mathrm{NaOH}$ (Treatment 3). For Treatments 1 and $2, \mathrm{HCN}$-p values were based on the $\mathrm{A}_{330}$ of reconstituted ether phases; for Treatment 3, values were based on 3-h gain in $\mathrm{A}_{330}$ following dilution of the extracts in $0.1 \mathrm{M} \mathrm{NaOH}(5)$. 
20 , and 24 October because the HCN-p of the frozen tissue decreased much more rapidly than that of the nonfrozen tissue. For KS8, the frozen tissue sampled on 14 October was somewhat higher in $\mathrm{HCN}-\mathrm{p}$ than the nonfrozen tissue, but as in the case of N32, the frozen tissue decreased in HCN-p more rapidly than did the nonfrozen tissue during the interval between 14 and 20 October. The KS8 samples were generally much lower in HCN-p than corresponding N32 samples, as was previously noted for upper leaves of fieldgrown plants (5).

Relatively mild temperatures prevailed between 24 October and 10 November, and only nonfrozen tissue was sampled during this interval. HCN-p values decreased somewhat during this period, but those for N32 remained quite high (Fig. 1). On the night of 10 November all tillers were frozen. HCN-p values obtained for N32 samples on 11 November (tissue frozen) were close to those obtained on 10 November (tissue not frozen). As the frozen tissue dried between 11 and 22 November, HCN-p values decreased steadily. For KS8 the decrease was less pronounced than for N32, but HCN-p levels throughout the period were much lower for KS8 than for N32.

We previously observed that upper leaves from main stems of $\mathrm{N} 32$ had considerably lower HCN-p values when the leaf tissue was autoclaved fresh than when the tissue was dried at $75^{\circ} \mathrm{C}$ before it was autoclaved (5). Compared to these earlier results, both frozen and nonfrozen tiller leaves showed a similar but much less pronounced effect of the oven treatment on HCN-p values (see Treatments 1 and 2, N32, Fig. 1).

Calculations of HCN-p following Treatments 1 and 2 were based upon the content of $p$-HB in reconstituted ether phases derived from autoclaved extracts. It is conceivable that in frozen tissue, virtually complete breakdown of dhurrin might have preceded harvesting and treatment of the samples, in which case $p-\mathrm{HB}$ might have remained in the tissue but $\mathrm{HCN}$ might have been lost by volatilization. In this event an assay dependent on the presence of dhurrin or cyanide as such would indicate low $\mathrm{HCN}$-p values, whereas an assay that depended only on the presence of $p$-HB would indicate high values. In Treatment 3 HCN-p values were based on gain in $\mathbf{A}_{330}$ resulting from the hydrolysis of dhurrin after leaf extracts were diluted in $0.1 \mathrm{M} \mathrm{NaOH}$. If no dhurrin remained in the tissue samples, this treatment would indicate very low $\mathrm{HCN}$-p values. The fact that $\mathrm{HCN}$-p values based on Treatment 3 were similar to those from Treatment 2 suggests that the $\mathrm{HCN}$-p values resulted from dhurrin that was still present, even in samples taken 6 or 7 days after the leaves were frozen. As shown in Fig. 1, samples of frozen N32 tillers harvested on 20 October and 17 November (following freezes on 13 October and 11 November, respectively) still had HCN-p levels about $500 \mathrm{mg} \mathrm{kg}^{-1}$ dry wt, a level that is considered potentially dangerous to grazing livestock (4).

To compare the results of the spectrophotometric assay for HCN-p with data obtained by use of an ionselective electrode, 20 of the KS8 and N32 tiller samples, ranging in HCN-p from $<100$ to $>2000 \mathrm{mg}$ $\mathrm{kg}^{-1}$ as assayed spectrophotometrically and including both frozen and nonfrozen samples, were assayed by distilling $\mathrm{HCN}$ from the tissue into $0.1 \mathrm{M} \mathrm{NaOH}$ and measuring the cyanide content of the resulting solution with a cyanide electrode. Values determined with the electrode were $1.28 \pm 0.05\left(\overline{\mathrm{x}} \pm \mathrm{s}_{\overline{\mathrm{x}}}\right)$ times as high as those determined in the spectrophotometric assay. The two sets of values were highly correlated $\left(\mathrm{r}=0.99^{* *}\right)$, indicating a high degree of reliability of the spectrophotometric method for assaying the HCN-p of these samples. The value of 1.28 and the correlation coefficient agree well with those reported earlier for the spectrophotometric and electrode methods of HCN-p determination (5).

An absorbance maximum at $280 \mathrm{~nm}$ was observed in basic solutions of reconstituted ether extracts derived from some of the samples of frozen tissue but not in extracts from nonfrozen samples. Basic solutions of $p$-hydroxybenzoic acid ( $p$-HBA) are characterized by an absorbance maximum at this wavelength. To investigate the possibility that $p$-HBA might be present in the frozen tissue, some of the

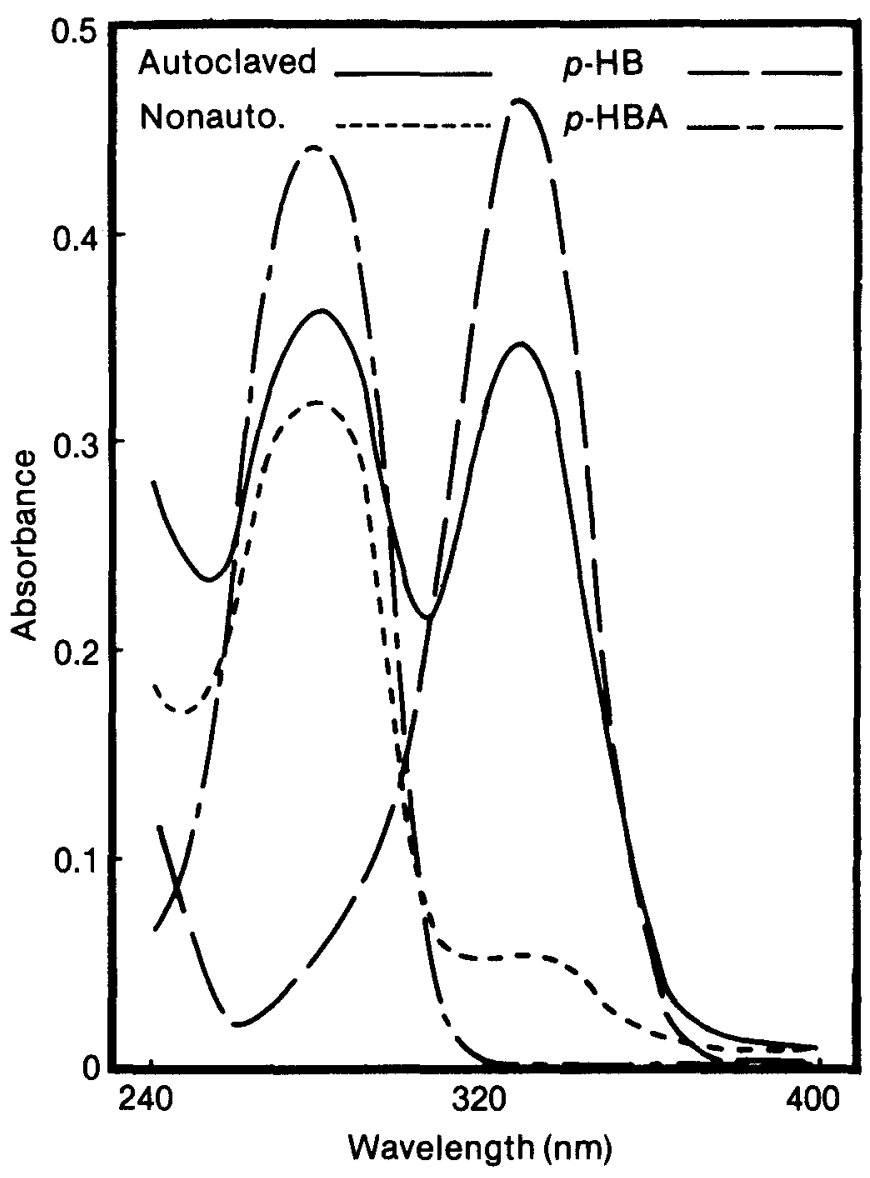

Fig. 2. Absorbance spectra of reconstituted ether phases resulting from autoclaved and nonautoclaved solutions from frozen N32 tiller leaves. The frozen leaf tissue was dried at $75^{\circ} \mathrm{C}$ for $2 \mathrm{~h}$, ground, and the equivalent of $2.00 \mathrm{~g}$ of fresh tissue was extracted in $100 \mathrm{~mL}$ of water at room temperature for $2 \mathrm{~h}$. One portion of the resulting solution was adjusted to $\mathrm{pH} 3.1$ and extracted with ether. Another portion was autoclaved for $30 \mathrm{~min}$ and then adjusted to $\mathrm{pH} 3.1$ and extracted with ether. Ether extracts were evaporated, brought back to the original volume with water (5), and diluted 10-fold with $0.1 M \mathrm{NaOH}$ for spectral scanning. Spectra of $p$-hydroxybenzaldehyde ( $p$ HB), $2.0 \mathrm{mg} \mathrm{L}^{-1}$, and $p$-hydroxybenzoic acid ( $p$-HBA), $3.5 \mathrm{mg}$ $L^{-1}$, in $0.1 M \mathrm{NaOH}$ are shown for comparison. 
Table 1. Chromatographic behavior of $p$-hydroxybenzaldehyde ( $p$-HB), $p$-hydroxybenzoic acid ( $p$-HBA), and the compound from frozen N32 tillers (Cpd. a). Ascending paper (Whatman no. 1) chromatography was used; values are means of three replications.

\begin{tabular}{|c|c|c|c|}
\hline \multirow{2}{*}{ Solvent system (Volumes in $\mathrm{mL}$ ) } & \multicolumn{3}{|c|}{$\operatorname{Rf}$ value $\left(\bar{x} \pm s_{\bar{x}}\right)$} \\
\hline & $p-\mathrm{HB}$ & $p$-HBA & Cpd. a \\
\hline n-Propanol $80: \mathrm{H}_{2} \mathrm{O} 20$ & $0.95 \pm<0.01$ & $0.88 \pm \quad 0.01$ & $0.88 \pm 0.01$ \\
\hline n-Propanol $80: 1 \%$ HAc 20 & $0.95 \pm<0.01$ & $0.95 \pm<0.01$ & $0.95 \pm<0.01$ \\
\hline n-Propanol $80: 1 \% \mathrm{NH}_{3} 20$ & $0.74 \pm 0.01$ & $0.37 \pm 0.01$ & $0.36 \pm<0.01$ \\
\hline n-Butanol 45:Pyridine $30: \mathrm{H}_{2} \mathrm{O} 22$ & $0.93 \pm 0.01$ & $0.71 \pm$ & $0.68 \pm 0.03$ \\
\hline n-Butanol 62:95\% Ethanol $17: \mathrm{H}_{2} \mathrm{O} 29$ & $0.95 \pm 0.01$ & $0.85 \pm$ & $0.84 \pm$ \\
\hline n-Butanol 60:Glacial HAc 5: $\mathrm{H}_{2} \mathrm{O} 25$ & $0.94 \pm \quad 0.01$ & $0.93 \pm$ & $0.93 \pm$ \\
\hline
\end{tabular}

frozen, dried, and ground tissue from the 22 November sampling of $\mathrm{N} 32$ was extracted with water at room temperature as in Treatments 2 and 3 . One portion

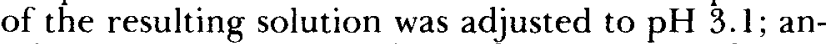
other portion was autoclaved for $30 \mathrm{~min}$ and then adjusted to $\mathrm{pH} 3.1$. Both portions were then extracted with ether, the ether was evaporated, and the solutions were reconstituted with water as previously described (5). (Although $p$-HB is efficiently extracted with ether at $\mathrm{pH} 6$, the original $\mathrm{pH}$ of the leaf extracts, $p$-HBA is not. Both $p$ - $\mathrm{HB}$ and $p$ - $\mathrm{HBA}$ are readily partitioned into ether at $\mathrm{pH} 3.1)$ As shown in Fig. 2 , the absorbance spectrum of the ether extract from the autoclaved solution had pronounced maxima at 330 and $280 \mathrm{~nm}$, suggesting the presence of $p-\mathrm{HB}$ and $p$-HBA, respectively. The nonautoclaved solution yielded an ether phase with a strong $280-\mathrm{nm}$ maximum but no definite maximum at $330 \mathrm{~nm}$ because most of the dhurrin, still intact at the time of ether extraction, remained in the aqueous phase. Support for the conclusion that the 280-nm-absorbing compound was $p$-HBA was obtained by comparing concentrated ether extracts derived from frozen N32 tissue with authentic $p$-HB and $p$-HBA on paper chromatograms. Both $p$-HB and $p$-HBA were detected on the chromatograms as absorbing spots under a $\mathrm{Mi}$ neralight Model R51 ultraviolet lamp. As shown in Table 1, the Rf of the compound from the tissue extract did not differ significantly from that of authentic $p$-HBA in any of the six chromatographic systems. Also, an extract derived from frozen N32 tiller leaves was chromatographed on a somewhat larger scale with n-propanol: $1 \% \mathrm{NH}_{3}(4: 1, \mathrm{v} / \mathrm{v})$ as the solvent, and the band with $\mathrm{Rf}$ corresponding to that of $p$-HBA was eluted for spectral scanning. The spectrum of this eluate was very similar to that of authentic $p$-HBA. These observations indicate that following freezing of the leaf tissue some of the dhurrin was degraded to $p$-HB, much of which was then oxidized to $p$-HBA.

Unlike previous experiments (e.g., 4, 9), our ex- periments did not disclose an increase in HCN-p following frost. Local weather conditions as well as differences in sample treatment and assay procedure may have affected the results of each investigation. We agree with the conclusion of Wattenbarger et al. (9) that following a killing frost, $\mathrm{HCN}-\mathrm{p}$ values decrease. This decrease may appear rather rapid, but our results suggest that in N32 tillers sufficient dhurrin may still be present 6 days after the tissue is killed to be of potential danger to livestock. We suggest that at least for sorghums with HCN-p levels similar to that of $\mathrm{N} 32$, the recommended waiting period of 3 days following a killing frost (4) may not be sufficient to provide safe forage. Allowing frost-killed sorghum plants to dry before they are grazed, as recommended by Dodds and Ball (2), would probably minimize the danger of cyanide poisoning.

\section{REFERENCES}

1. Association of Official Agricultural Chemists. 1945. Methods of Analysis, 6th ed. Association of Official Agricultural Chemists. Washington, DC p. 416.

2. Dodds, D.L., and W.S. Ball. 1982. Sorghum and sudangrass for forage in North Dakota. N.D. Coop. Ext. Serv. Circ. R-762.

3. Gorz, H.J., W.L. Haag, J.E. Specht, and F.A. Haskins. 1977. Assay of $p$-hydroxybenzaldehyde as a measure of hydrocyanic acid potential in sorghums. Crop Sci. 17:578-582.

4. Harrington, J.D. 1966. Hydrocyanic acid content of Piper, Trudan I, and six sorghum-sudangrass hybrids. Penn. State Univ. Agric. Exp. Stn. Bull. 735.

5. Haskins, F.A., H.J. Gorz, R.M. Hill, and J.B. Youngquist. 1984. Influence of sample treatment on apparent hydrocyanic acid potential of sorghum leaf tissue. Crop Sci. 24:1158-1163.

6. Kojima, M., J.E. Poulton, S.S. Thayer, and E.E. Conn. 1979. Tissue distributions of dhurrin and of enzymes involved in its metabolism in leaves of Sorghum bicolor. Plant Physiol. 63:10221028.

7. Ross, W.M., A.J. Casady, J.R. Lawless, and F.L. Barnett. 1972. Registration of 29 Sorghum parental lines. Crop Sci. 12:722.

8. - - H.J. Gorz, F.A. Haskins, and O.J. Webster. 1980. Registration of ten sorghum parental lines. Crop Sci. 20:834.

9. Wattenbarger, D.W., E. Gray, J.S. Rice, and J.H. Reynolds. 1968. Effects of frost and freezing on hydrocyanic acid potential of sorghum plants. Crop Sci. 8:526-528. 